\title{
Vocational Training and Basic Knowledge of the Mexican University Coach
}

\author{
Ciria Margarita Salazara, Julio Alejandro Gómez Figueroab, Martha Patricia Pérez Lópeza, Carmen \\ Silvia Vargas Peñaa, Pedro Julián Flores Morenoa, Rossana Tamara Medina Valenciaa , José E. Del Rio \\ Valdiviaa , José Aldo Hernández-Murúac
}

\begin{abstract}
This paper shows an overview of the academic and vocational training of the Mexican university coaches. Professional sports in Mexico are not sufficiently organized in all disciplines and the Olympic sporting system does not consider the university sports as a hotbed of world-class athletes. Coaches' academic and vocational training is one of the variables to analyze university-sporting level. A quantitative model was used to approach the topic through an adapted and validated version of a questionnaire used in Spanish populations. The sample consisted of 326 participant's coaches at the 2013 National Student Games. Among the findings, observed there are some aspects revealed related to the training, the domain of knowledge and the existing relationship between an empirical coach and a trained one. In conclusion, therefore, it is important to emphasize that the non-skilled trainer finds it difficult to achieve the optimum sport development, the fulfillment of the assigned tasks, the selection, the dosage, the linking of different means, and the assessment of achievement. According to the national sport level, the university trainer's profile neither allows the consolidation of practice nor these ages and sport levels.
\end{abstract}

\section{Keywords}

University coach, training, professional and academic profile

Since 1856, practices of self-expression through movement are introduced to the curriculum of the Mexican education system (Santoyo 2012; Villalpando 2013) with a strong influence of Swedish-German gymnastics and later on the French School. In those days, it was important to model and generate elements of body control that could be useful to the hygienist and military state paradigm.

At the end of the nineteenth century and until 1920, those bodily practices were only exclusive to popular school centers, however, the European integration influence at that time, flourished in the Mexican economy and culture, moving forward to new uses of time in leisure and sport activities.

In this period, the practice of swimming proliferates, apart from fencing, ball sports (particularly basket ball and soccer), and preferably tennis in private clubs.

In March 1923, the elementary school of physical education is created to instruct the replicators of the contents which by then were taught in Mexican elementary school. From that moment on, forming

\footnotetext{
aUniversity of Colima, México

bUniversity of Veracruz, México

cAutonomous University of Sinaloa, México

\section{Correspondent Author:}

Pedro Julián Flores Moreno, Alemania 1771 street, Col. Margaritas, Zip code: 28047. Colima, Colima, Mexico E-mail: pedrojulian_flores@ucol.mx
} 
schools were opened and closed due to government's imprecisions and instability. It is until 1949, when National School of Physical Education (NSPE) was instituted. Due to the demand for higher qualifications prior to basic education, the School of Physical Education was created in 1976 to date (Aguilar 2003; Santoyo 2012). Subsequent to the emergence of NSPE, higher educational schools and university forming programs emerged (Zueck, Chávez, and Blanco 2009). Since then, the same educational programs that have trained physical education teachers with profile of graduation have influenced psychomotor and development of sporting talent formative aspects.

This generalist profile initially allowed the physical education teachers to be the sporting coaches of the twenties. Then, successful athletes by the overwhelmed need for the sporting practice and lack of physical education teachers, performed the task of coaches replicating everything learned when they were athletes. In this way, Mexico was confronting international sporting commitments, sometimes coming out winners and in many occasions as losers.

This empirical coach practice was legitimized with some international successes, a situation that still remains but does not generate to Mexican athletes an optimal development of their conditional abilities. By 1987, a training program Centro de Educación Continua de Estudios Superiores del Deporte (CECESD) or Continuous Education Center for Higher Studies of Sport, arose for coaches at the Autonomous National University of Mexico (ANUM) that enabled hundreds of coaches in 19 disciplines with a length of three years, 3,000 hours and 300 credits; these new coaches had at least completed high school studies and had minimum experience as an athlete (Runne 1995). Not being given enough universities' proposals and deemed a not much accessible format for more empirical coaches, the Mexican President Carlos Salinas de Gortari decreed the creation of the Comisión Nacional del Deporte (CONADE) or National Sports Commission in 1988.
This administrative office has the responsibility to manage actions and policies for the development of the sport's high competition and the social physical activities and practices ${ }^{1}$.

CONADE founded the Escuela Nacional de Entrenadores Deportivos (ENED) or National School of Sporting Coaches with the aim of training coaches with scientific and methodological elements that respond to the needs of Mexican sports.

However, a national school was not enough to attend the populations' sporting practices' demands, tracking sports talents in each State of the Republic and much less for the training of the high performance athletes. Therefore, in 1995, it was decided to create the Sistema de Capacitación y Certificación para Entrenadores Deportivos (SICCED) or Training and Certificate System for Sporting Coaches. Thousands of empirical sporting coaches were accredited by attending this mandatory program in order to coach any kind of competitions ${ }^{2}$.

This measure pushed to seek the accreditation of professionals in sport and physical activity and other related professions as well as coaches who were athletes and now at the head of a team. The SICCED certification card guarantees the mastery of the key elements about athletes' coaching and leading, attending this course in weekend sessions. This accreditation enables professionals to become national coaches in any discipline.

In Mexico, the elite athlete's competitive course is designed by the Mexican Sporting System - CONADE - and primarily consists of four stages: The first one is sporting initiation in clubs, private schools, or receiving municipal programs of talented athletes aged from 6 to 12; the second stage is the sporting prospectus development in a competition called National Junior Olympiad for 11 to 18 years old; the third stage is the sporting improvement that occurs between 19 and 27 and academically coincides with the athletes' stay in undergraduate and postgraduate studies, for this stage, the National Student Games 
(municipal, regional, and national final teams) have been designed; and the fourth stage is the selective national team, stage that it is characterized by the optimum sporting performance were the age can range from 17 to 35 years old; but it will all depend on the sporting excellence performed by the athlete which is the last bracket of the elite athlete's career. Therefore, the university stage becomes a breaking point for athletes who want to achieve a place in the Mexican elite team.

In countries such as Australia, the United States, and Canada, college athletics is a vital link for the development of Olympic and professional sport. As noted below in a study about college athletics models (Terol 2004):

The role of the universities regarding the high performance or elite sport is basic and expresses both in the direct contribution of athletes to the national representation team as the creation of high performance centers of excellence, linked and depending on the universities management. (Terol 2004: 218)

This management is not only limited to constitute selective athletes and send them to the competitions, it engages throughout a work plan that integrates from a sporting policy in the university agenda till all the services and processes professionalization with the highest quality. The quality of each piece of the structure is properly planned and constantly evaluated. Coaches' staff is composed by experts in each of the needs required by the athlete to reach the goals. The coach is required to have professional and specialized knowledge of their sport, as they will have to lead a team of 10 or more experts to achieve the athletes' high performance (Terol 2004).

The so-called Consejo Nacional del Deporte de la Educación (CONDDE) or National Council of Sport's Education is an institution originated in 1947, it is economically dependent from the country's education system and all the Mexican college athletics relapse in it. So far, it has been used to organize college athletics competitions and to select the Mexican competitors who will represent the country every two years at the World Student Games. Its powers are limited to those two activities being the Mexican universities or the own athletes who pay for the sporting development.

This autonomy and the discouragement to implement a sporting policy in Mexican universities allow conflicting situations and practices in the professionalization of the sporting development processes of their athletes.

It is precisely the presence of professionals and experts who should lead the processes of development and the athletes' sporting success; in saying process, the coach plays an important role. Baker et al. (2003) in Martin and Ruiz (2010) proved in an Olympic athletes' study that a good expert coach is the factor for sporting success; Guinan (2002) provided that Olympic athletes perceive higher performance when the coach can demonstrate their knowledge and experience.

Reasons for school, club, or sporting organizations put their athletes in the hands of coaches with "Knowledge of the specific multidimensional nature of its sporting environment, so this knowledge level and its application have a direct effect on the athletic training session process" (Lyle 2000, quoted by Irwin, Hanton, and Kerwin 2004).

In the conceptual revision to define coach and its professional characteristics, the expressions through dictionaries are reductive ranging from: individual coaching, prepares athletes, or trains an animal.

However, sporting literature proposes other skills and competences of the sporting coach:

A competent person who leads the training and the competitions, as well as the knowledge and skills necessary for all PE (physical education) and sporting teacher, the coach should possess specific knowledge in their specialty (sporting discipline) and, above all theory's athletic training. Usually, the basis for this is next to a suitable training, personal training experience and competition. (Sport Science Dictionary 1992: 710) 
Besides the basic knowledge of the discipline, the coach requires ability and skills in the use of the sporting education, which is noticeably in the capability of adapting the sessions to the individual and attitudinal characteristics of the athlete (Platonov 1999); knowledge that must be learned by coaches based on training theoretical frameworks.

In addition to starting professional training, the coaches have the need and responsibility to continue training and learning throughout their professional life mostly in pseudo-scientific programs, incorporating the advanced training studies in medicine, technology, and software computing (Platonov 1999; Jiménez Fuentes 2003).

\section{STUDIES ABOUT COACHING TRAINING}

Coaching training studies started in the 1970s by Tausch's first scientific contributions, Tausch (1977), Chelladurai and Hanggery (1978), Bauer and Ueberle (1984) in Moreno and Del Villar (2004) related to the professional development, the methods or instruction's styles and the contents transmitted. In 1989, Martens and best qualified colleagues, added three different training styles to the chain of formal and informal contributions that coaches had included before.

Unlike the physical education teacher-training studies, training coaches is in its early age in Spain. Gonzalez, Monterrey, and De las Cuevas (1989), and lately, by Ibáñez and Medina (1999), Feu and Ibáñez (2001), Feu et al. (2009), Feu, Ibañez, and Gozalo (2010), and Feu et al. (2012) focused on formal knowledge in handball, basketball, and basketball coaches (Abad et al. 2011), continuous training, empirical knowledge against those acquired in vocational training; Yagüe, Fraile, and Rodríguez (2004), and Sanz et al. (2004) have adapted their contributions to the continuous training of coaches.

In Mexico, León et al. (2007) carried out an analysis about the current situation in sport-school education and development process in Cajame, Sonora, such study showed the different deficiencies in the process of planning, implementation, and professional-sport training. Six years later, Nava, Flores, and Gómez (2013) added a diagnosis in Mexico about the abilities of coaches from the Instituto Tecnológico de Sonora (Institute Technological of Sonora) in the process of planning, implementation, and training evaluation, finding the opposite from the first analysis. The most relevant of the previous study is the observation unit focused on college sport level.

In Colima, Mexico, teachers training studies have been found (Medina et al. 2012a; Medina et al. 2012b) at a curricular level and exploratory works have been made in the area of professional training coaches of the elite youth teams, Méndez (2012) and Urzúa (2013) in the disciplines of Tennis. Guillen and Ricarte (2014) made a comparison between handball and soccer coaches to analyze the differences in the application of knowledge in medalist coaches and losing teams, the outcome, the handball coaches are certified in physical education training, as opposite to the soccer coaches who are certified in basic sport training courses (SICCED). Another contribution to this study is that handball coaches apply professional knowledge training and the soccer coaches use empirical skills.

Recently, a research team made by academics from the Universities of Colima, Veracruz and Sinaloa (these last two universities were recently the headquarters of the National University Level Games, respectively in 2012 and 2013), resumes the previous literature and has followed the coaches of the highest amateur-elite category on the national finals in Mexico for two years in order to determine the professional knowledge acquired by the Mexican coach at university level from their experiences of formal and non-formal training as well as the knowledge application.

The objective of the current exploration is to identify the acquired vocational training in sports, mastery knowledge, and skills used as a coach. 


\section{MATERIAL AND METHODOLOGIES}

This investigation is a cross-sectional descriptive study (Hernandez, Fernández, and Baptista 2009). The study is a collection of 326 Mexican coaches' impressions (32 women and 294 men, 30-40 age average) that represent universities across the country. The survey technique was used in this study by a random probabilistic sample (Zorrilla 1999), considering a $95 \%$ confidence and $5 \%$ error rate.

The subjects were selected by gender and the sport discipline, the representativeness in these two aspects was attempted to determine the competition and variability of population (Ara and Saboya 2006).

The "questionnaire on coaches' training of Mexican university sport" was the instrument used for the collection of information and adapted to Mexican populations from the original version (Feu 2006). The values of trust worthiness in the instrument are $\alpha=87$ to an optimal consistency in the scale. The first part of the survey had 98 questions about nominal answers which collected the socio-demographic data. In second part, the Likert scale was used to collect the ordinal answers. In the survey, the number 1 means "being totally disagree" and the number 5 means "being totally agree". The categories in the survey include socio-demographic data, initial training, lifelong training, knowledge acquired as a coach and professional knowledge training. However, for this study, only two categories are used.

The application of the instrument was verified on a pilot manner at the National Student Games finals (end of April) in 2012 and the sample phase at the last National Student Games in May 2013. The systematization data process and the descriptive statistical analysis were performed by the SPSS (Statistic Package for Social Science) Version 19. Descriptive statistics and contingency tables were used to establish crossings between variables and ANOVA (Analysis of Variance) intra-groups were carried out to determine the significance level between the analyses of the subgroups. In the case of Table 3, every vocational training group was classified as a subgroup with sports specialty.

\section{RESULTS}

The information is organized into two parts: firstly, the socio-demographic knowledge that implies knowing the type of vocational training and professional sports training that the national finalists' coaches have; secondly, the type ofmastery and application that participants have in the sports training theory.

In Table 1, the preponderance of men at the head of the Mexican university teams can be observed, as well as the fact that the average coaches' age is from 30 to 50 years old, more than 10 years experience at the head of sporting teams; regarding the level of education, the Bachelor of Science degree is prevailing, then Master and Ph.D. degrees. However, $40 \%$ of the coaches at the head of sporting teams do not have higher education degrees related to sports science or similar. A $97.2 \%$ (317) of the coaches were players of the same sport than now they coach and $2.8 \%$ (9) have never played any sports before.

Analyzing the higher academic sports training degree, we can observe that the $40.5 \%(n=132)$ do not have any sports training experience. The rest of the group have a specialized training. Physical Education Bachelor of Science degree is prevailing $(45.1 \%-\mathrm{n}=147)$. Concerning the gender, women have the greatest concentration in Physical Education Bachelors of Science degree $(50 \%-\mathrm{n}=16)$ and postgraduate studies $(21.9 \%-\mathrm{n}=7)$. Unlike men, there are the same number of coaches with academic specialized training $(44.6 \%-\mathrm{n}=131)$ and without academic specialized training $(42.8 \%-\mathrm{n}=123)$ (see Table 2).

As regards the second analysis category corresponding to the knowledge required by a coach to be at the head of a team or guiding an athlete (Feu 2004), we can distinguish some related findings with 
Table 1. General Population Study

\begin{tabular}{ll}
\hline Gender & 32 \\
\hline Women & 294 \\
Men & \\
\hline Ages & --- \\
\hline-20 & 57 \\
+20 & 97 \\
+30 & 92 \\
+40 & 65 \\
+50 & 15 \\
+60 & \\
\hline Experience & 26 \\
\hline 1-2 years & 35 \\
$3-5$ years & 77 \\
6-10 years & 67 \\
11-15 years & 121 \\
+16 years & \\
\hline Schooling & ---- \\
Elementary & 1 \\
Middle school & 31 \\
High school & 215 \\
Bachelor degree & 67 \\
Master & 12 \\
Ph.D. & \\
\hline Sporting training & 132 \\
\hline Nobody & 147 \\
Bachelor degree & 44 \\
Master & 3 \\
Ph.D. & 183 \\
Type of sport & 143 \\
\hline Singles & 9 \\
Team & \\
\hline Athlete of the sport's coaching & \\
\hline Yes & \\
No & \\
\hline
\end{tabular}

Table 2. Highest Academic Sports Training Bachelors of Science Degree

\begin{tabular}{llllll}
\hline \multirow{2}{*}{ Category } & $\begin{array}{l}\text { Without academic } \\
\text { specialized training }\end{array}$ & $\begin{array}{l}\text { Physical education } \\
\text { bachelors of science } \\
\text { degree }\end{array}$ & $\begin{array}{l}\text { Master of science in } \\
\text { physical education } \\
\text { degree }\end{array}$ & $\begin{array}{l}\text { Ph.D. in physical } \\
\text { education degree }\end{array}$ & Total \\
\cline { 2 - 6 } & $40.5 \%(132)$ & $45.1 \%(147)$ & $13.5 \%(44)$ & $.9 \%(3)$ & $100 \%(326)$ \\
\hline Age & & & & & \\
\hline+20 & $45.6 \%(26)$ & $49.0 \%(28)$ & $5.3 \%(3)$ & $.0 \%(0)$ & $17.5 \%(57)$ \\
+30 & $33.0 \%(32)$ & $47.4 \%(46)$ & $18.6 \%(18)$ & $1.0 \%(1)$ & $29.8 \%(97)$ \\
+40 & $42.4 \%(39)$ & $44.6 \%(41)$ & $13.0 \%(12)$ & $.0 \%(0)$ & $28.2 \%(92)$ \\
+50 & $40.0 \%(26)$ & $41.5 \%(27)$ & $15.4 \%(10)$ & $3.1 \%(2)$ & $19.9 \%(65)$ \\
+60 & $60.0 \%(9)$ & $33.3 \%(5)$ & $6.7 \%(1)$ & $.0 \%(0)$ & $4.6 \%(15)$ \\
\hline
\end{tabular}


Table 2 continued

\begin{tabular}{|c|c|c|c|c|c|}
\hline \multirow[t]{2}{*}{ Category } & $\begin{array}{l}\text { Without academic } \\
\text { specialized training }\end{array}$ & $\begin{array}{l}\text { Physical education } \\
\text { bachelors of science } \\
\text { degree }\end{array}$ & $\begin{array}{l}\text { Master of science in } \\
\text { physical education } \\
\text { degree }\end{array}$ & $\begin{array}{l}\text { Ph.D. in physical } \\
\text { education degree }\end{array}$ & Total \\
\hline & $40.5 \%(132)$ & $45.1 \%(147)$ & $13.5 \%(44)$ & $.9 \%(3)$ & $100 \%(326)$ \\
\hline \multicolumn{6}{|l|}{ Gender } \\
\hline Woman & $28.1 \%(9)$ & $50.0 \%(16)$ & $21.9 \%(7)$ & $.0 \%(0)$ & $9.8 \%(32)$ \\
\hline Men & $41.8 \%(123)$ & $44.6 \%(131)$ & $12.6 \%(37)$ & $1.0 \%(3)$ & $90.2 \%(294)$ \\
\hline \multicolumn{6}{|c|}{ Years of experience } \\
\hline $1-2$ years & $50 \%(13)$ & $46.2 \%(12)$ & $3.8 \%(1)$ & $.0 \%(0)$ & $8.0 \%(26)$ \\
\hline $3-5$ yeas & $37.1 \%(13)$ & $45.7 \%(16)$ & $14.3 \%(5)$ & $2.9 \%(1)$ & $10.7 \%(35)$ \\
\hline 6-10 years & $35.1 \%(27)$ & $54.5 \%(42)$ & $10.4 \%(8)$ & $.0 \%(0)$ & $23.6 \%(77)$ \\
\hline $11-15$ years & $37.3 \%(25)$ & $50.7 \%(34)$ & $10.4 \%(7)$ & $1.5 \%(1)$ & $20.6 \%(67)$ \\
\hline Over 16 years & $44.6 \%(54)$ & $35.5 \%(43)$ & $19.0 \%(23)$ & $.8 \%(1)$ & $37.1 \%(121)$ \\
\hline \multicolumn{6}{|l|}{ Sport } \\
\hline Single & $50.3 \%(92)$ & $37.2 \%(68)$ & $11.5 \%(21)$ & $1.1 \%(2)$ & $56.1 \%(183)$ \\
\hline Team & $28.0 \%(40)$ & $55.2 \%(79)$ & $16.1 \%(23)$ & $.7 \%(1)$ & $43.9 \%(143)$ \\
\hline
\end{tabular}

the type and sporting training level and the basic academic knowledge of the university coaches related to teams and athletes at the National Student Games finals.

Table 3 is about the minimal knowledge that a coach has concerned on local teams and high performance athletes. The result is the percent value accumulated by the type of sports training or the related area.

In each group, $50 \%$ of the subjects have basic knowledge in most of the topics. Otherwise, in the common knowledge of the sports practice such as regulations, sporting technique and tactic, they hardly pass the $60 \%$. In medical, biology and psychology knowledge, as well as the applied science and Information and Communication Technologies, the four groups have lack of skills.

On the significant differences at sports training levels, the postgraduate coaches have more knowledge in the technique and tactic, strategy and team management, they have pedagogical knowledge, teaching methods, and they know the sport at university level .005.
About professional knowledge used by Mexican coaches at university level, the authors note that the acquired knowledge prevail in the disciplinary training courses $(42.3 \%-n=138)$, the second option, learned knowledge during the genetic trainings courses $(42.4 \%-\mathrm{n}=133)$. The least used, the self-taught knowledge $(8.9 \%-n=29)$ (see Table 4$)$.

\section{DISCUSSION}

The two categories of analysis given above show that even being coaches at a high-university competition level, representative of an education system (university) and coach finalist of the highest national competition, previous experience, empiricism (Feu, Ibañez, and Gozalo 2010; Feu et al. 2012) and popular belief (López 2004) has more weight regarding on the basic knowledge of sporting training's essential elements.

In some basic topics of knowledge, coaches with vocational training in sports and related areas, use less the experience and learning acquired as a player and more the knowledge acquired in their professional life. A Spanish study performed by Feu et al. (2012), found 
Table 3. Mastery of Basics Knowledge by Vocational Training Level

\begin{tabular}{|c|c|c|c|c|c|}
\hline Knowledge's topic & NTP & BPE & MPES & PhDPES & Sig. \\
\hline General theory of athletic training-general physical conditioning & 41.7 & 42.2 & 61.7 & 66.7 & .470 \\
\hline $\begin{array}{l}\text { General theory of athletic training-physical conditioning for high } \\
\text { performance or university athletes }\end{array}$ & 41.7 & 46.9 & 65.9 & 66.7 & .518 \\
\hline $\begin{array}{l}\text { General theory of athletic training-principles and methods of athletic } \\
\text { training }\end{array}$ & 39.4 & 39.5 & 68.2 & 66.7 & .604 \\
\hline Knowledge of the sport that I coach-technique and tactics of sports & 55.3 & 61.9 & 72.7 & 66.7 & $.037^{*}$ \\
\hline Knowledge of the sport that I coach-strategy and team management & 47 & 55.1 & 68.2 & 66.7 & $.024^{*}$ \\
\hline Knowledge of the sport that I coach-physical training applied to sports & 42.4 & 55.8 & 63.6 & 33.3 & .275 \\
\hline Knowledge of the sport that I coach-games regulations & 60.6 & 64.6 & 79.5 & 33.3 & .126 \\
\hline $\begin{array}{l}\text { Knowledge of the sport that I coach-technical and tactical contents most } \\
\text { appropriate for university high performance }\end{array}$ & 43.9 & 55.1 & 70.5 & 0 & $.047^{*}$ \\
\hline Educational knowledge-methods and styles of teaching & 33.3 & 50.3 & 61.4 & 66.7 & $.045^{*}$ \\
\hline Educational knowledge-planning and programming of sports' teaching & 40.2 & 55.8 & 54.5 & 66.7 & .132 \\
\hline $\begin{array}{l}\text { Educational knowledge-observation, analysis, and evaluation of athletic } \\
\text { training }\end{array}$ & 36.4 & 51.7 & 59.1 & 33.3 & .423 \\
\hline $\begin{array}{l}\text { Educational knowledge-methods of sports adapted to teach in university } \\
\text { high performance }\end{array}$ & 34.1 & 44.9 & 40.9 & 33.1 & .662 \\
\hline $\begin{array}{l}\text { Knowledge of physical education-psychomotor development of } \\
\text { schoolchildren }\end{array}$ & 26.5 & 44.9 & 52.3 & 0 & .250 \\
\hline Knowledge of physical education-education values through sports & 47 & 56.5 & 63.6 & 0 & .476 \\
\hline $\begin{array}{l}\text { Knowledge management-organization of athletic training resources } \\
\text { (facilities, equipment, schedules, travel, etc.) }\end{array}$ & 40.2 & 45.6 & 65.9 & 33.3 & .556 \\
\hline $\begin{array}{l}\text { Knowledge management-enrollment of the team and pooling and } \\
\text { registration of athletes }\end{array}$ & 36.4 & 38.8 & 42.5 & 33.9 & .763 \\
\hline Sporting medicine-physiological and anatomical aspects of the athletes & 29.5 & 37.6 & 33.3 & 34.4 & .999 \\
\hline $\begin{array}{l}\text { Sporting medicine-evolution of the biological-physiological condition in } \\
\text { university athletes }\end{array}$ & 27.3 & 36.1 & 43.2 & 33.3 & .361 \\
\hline Sporting medicine-first aid & 25.8 & 42.2 & 40.9 & 33.3 & .589 \\
\hline $\begin{array}{l}\text { Sport psychology-evolutionary psychology and psychological aspects in } \\
\text { university athletes }\end{array}$ & 27.3 & 29.3 & 34.1 & 0 & .249 \\
\hline Sport psychology-leadership skills or cohesion in the team & 34.8 & 43.5 & 52.3 & 33.3 & .773 \\
\hline Sport psychology-motivational skills & 37.9 & 37.4 & 59.1 & 0 & .605 \\
\hline $\begin{array}{l}\text { Sport psychology—communication skills and relationship with athletes and } \\
\text { parents }\end{array}$ & 40.2 & 35.4 & 50 & 66.7 & .490 \\
\hline Sport psychology—athletes' training of psychological techniques for sports & 27.3 & 34 & 38.6 & 0 & .764 \\
\hline $\begin{array}{l}\text { Knowledge of new technologies applied to sport-use databases and } \\
\text { spreadsheets for the monitoring and recording of my athletes }\end{array}$ & 28.8 & 29.3 & 50 & 33.3 & .907 \\
\hline $\begin{array}{l}\text { Knowledge of new technologies applied to sport-use presentations to } \\
\text { teach theoretical content, graphics... (power point) }\end{array}$ & 31.1 & 29.3 & 50 & 33.3 & .535 \\
\hline $\begin{array}{l}\text { Knowledge of new technologies applied to sport-use video to analyze the } \\
\text { athletes training sessions and competition }\end{array}$ & 34.8 & 36.7 & 63.6 & 33.3 & .875 \\
\hline Professional development and ethics-sport's organization and legislation & 24.2 & 33.3 & 52.3 & 33.3 & .397 \\
\hline $\begin{array}{l}\text { Professional development and ethics-labor legislation that affects the } \\
\text { coach }\end{array}$ & 22.7 & 25.2 & 38.6 & 33.3 & .628 \\
\hline Professional development and ethics-coach's civil liability & 31.8 & 36.7 & 56.8 & 100 & .213 \\
\hline Professional development and ethics-ethics in the athletes' training & 52.3 & 48.3 & 72.7 & 33.3 & .265 \\
\hline
\end{tabular}

Notes: ${ }^{*}$-intra group statistical significance. NPT = none previous training, BPE = Bachelor degree in Physical Education, MPES = Master in Physical Education and Sport, PhDPES = Ph.D. in Physical Education and Sport. 
Table 4. Professional Knowledge Used

\begin{tabular}{|c|c|c|c|c|c|}
\hline & 1 & 2 & 3 & 4 & 5 \\
\hline $\begin{array}{l}\text { I learned by myself neither using the help of any } \\
\text { course nor the assistance of anybody else }\end{array}$ & $32.2 \%(105)$ & $15.6 \%(51)$ & $26.7 \%(87)$ & $16.6 \%(54)$ & $8.9 \%(29)$ \\
\hline The methods used by my coaches during my training & $7.7 \%(25)$ & $12.9 \%(42)$ & $39.3 \%(128)$ & $25.2 \%(82)$ & $15.0 \%(49)$ \\
\hline $\begin{array}{l}\text { Resolve the problems that during my training using my } \\
\text { own methods }\end{array}$ & $15.6 \%(51)$ & $19.3 \%(63)$ & $28.8 \%(94)$ & $20.9 \%(68)$ & $15.3 \%(50)$ \\
\hline $\begin{array}{l}\text { My experience as a player is a great help, motivating my } \\
\text { players }\end{array}$ & $4.6 \%(15)$ & $3.4 \%(11)$ & $16.3 \%(53)$ & $35.0 \%(114)$ & $40.8 \%(133)$ \\
\hline $\begin{array}{l}\text { The learned knowledge I have acquired during my } \\
\text { training courses }\end{array}$ & $2.5 \%(8)$ & $4.6 \%(15)$ & $11.3 \%(37)$ & $40.2 \%(131)$ & $41.4 \%(135)$ \\
\hline The acquired knowledge when I was a player & $2.1 \%(7)$ & $4.9 \%$ & $19.0 \%(62)$ & $37.4 \%(122)$ & $36.5 \%(119)$ \\
\hline $\begin{array}{l}\text { The acquired knowledge during learned training } \\
\text { courses }\end{array}$ & $2.8 \%(9)$ & $2.5 \%(8)$ & $14.1 \%(46)$ & $41.4 \%(135)$ & $39.3 \%(128)$ \\
\hline My own methods used by experience & $3.1 \%(10)$ & $7.1 \%(23)$ & $26.1 \%(85)$ & $34.7 \%(113)$ & $29.1 \%(95)$ \\
\hline $\begin{array}{l}\text { edge in the psychological aspects } \\
\text { players }\end{array}$ & $2.8 \%(9)$ & $5.8 \%(19)$ & $16.0 \%(52)$ & $39.3 \%(128)$ & $36.2 \%(118)$ \\
\hline I learned about my sport during my training courses & $1.8 \%(6)$ & $2.5 \%(8)$ & $13.2 \%(43)$ & $40.2 \%(131)$ & $42.3 \%(138)$ \\
\hline ner coaches when I was a player & $3.7 \%(12)$ & $6.4 \%(21)$ & $24.5 \%(80)$ & $33.1 \%(108)$ & $32.2 \%(105)$ \\
\hline $\begin{array}{l}\text { The evaluation techniques that I have learn in my } \\
\text { training courses }\end{array}$ & $2.8 \%(9)$ & $5.5 \%(18)$ & $19.0 \%(62)$ & $35.9 \%(117)$ & $36.8 \%(120)$ \\
\hline $\begin{array}{l}\text { The strategies that my coaches used to analyzed the } \\
\text { development of our team }\end{array}$ & $4.3 \%(14)$ & $8.6 \%(28)$ & $30.1 \%(98)$ & $34.4 \%(112)$ & $22.7 \%(74)$ \\
\hline $\begin{array}{l}\text { The methodologies that I have learned during my } \\
\text { training courses }\end{array}$ & $2.8 \%(9)$ & $3.1 \%(10)$ & $13.2 \%(43)$ & $43.3 \%(141)$ & $37.7 \%(123)$ \\
\hline I keep up the motivation through my own strategies & $8.3 \%(27)$ & $12.9 \%(42)$ & $25.8 \%(84)$ & $31.0 \%(101)$ & $22.1 \%(72)$ \\
\hline $\begin{array}{l}\text { The exercises and task that I learned when I was a } \\
\text { player }\end{array}$ & $5.5 \%(18)$ & $8.6 \%(28)$ & $28.2 \%(92)$ & $31.6 \%(103)$ & $26.1 \%(85)$ \\
\hline $\begin{array}{l}\text { The exercises and tasks I learned in the training } \\
\text { courses, books, and magazines }\end{array}$ & $1.8 \%(6)$ & $4.3 \%(14)$ & $19.3 \%(63)$ & $40.8 \%(133)$ & $33.7 \%(110)$ \\
\hline The acquired experience about my own exercises & $7.7 \%(25)$ & $15.3 \%(50)$ & $30.4 \%(99)$ & $25.8 \%(84)$ & $20.9 \%(68)$ \\
\hline $\begin{array}{l}\text { Solving the problems using my own experiences } \\
\text { when I was a player }\end{array}$ & $4.6 \%(15)$ & $6.1 \%(20)$ & $31.0 \%(101)$ & $29.8 \%(97)$ & $28.5 \%(93)$ \\
\hline $\begin{array}{l}\text { Facing the problems using the knowledge I have } \\
\text { learned in the courses }\end{array}$ & $3.4 \%(11)$ & $1.8 \%(6)$ & $17.8 \%(58)$ & $41.7 \%(136)$ & $35.3 \%(115)$ \\
\hline $\begin{array}{l}\text { The experience skills I have acquired to the analysis } \\
\text { of my won team }\end{array}$ & $1.5 \%(5)$ & $3.1 \%(10)$ & $13.2 \%(43)$ & $39.9 \%(130)$ & $42.3 \%(138)$ \\
\hline
\end{tabular}

that handball coaches with most sporting training diminished the option to act as reconverted athlete.

Although, the average, in the assessment of basic knowledge about sporting training, was medium-low to medium with mastery of medium-high by coaches with advanced studies in four of 27 topics in the sport's item. The higher level of initial training relates to higher knowledge concurring with the study carried out by Feu et al. (2010) in Spain with handball coaches; and in the case of Mexican university coaches, those with postgraduate education in areas of sporting training had greater mastery of basics knowledge.

It is clear that the training curriculum for the physical and sport educators is not functional (Barros et al. 2010) and it does not guarantee anything to attend at the high performance university sports level that requires this level teams. Ibañez and Medina (2006) mentioned that the close relationship between initial training of the PE (physical education) teacher and the coach's training is obvious, but divergent in continuing 
training because the performance areas are different (Ibáñez and Medina 2000), therefore, the Mexican university sport and national sport systems should consider transfers' mechanisms of specialized knowledge for the type of sports, high performance sporting level, and a specific knowledge training for each discipline (Feu et al. 2009). Being higher class education programs directed in research, with the required characteristics to lead teams in national final, didactic innovations, training theory and use of new applied technologies for efficiency training (Jiménez Fuentes 2003).

In this research, the authors analyze the basic knowledge and the university coach's profile of the national finals, although, they are a fundamental key in developing sporting talent and high performance athletes; the Mexican university sport structure must migrate to an overall system (López and González 2012), become more modern, revising regulations, competitive processes, financing mechanisms and technical academic strategies to develop the national students teams (Feu and Ibañez 2001).

Terol (2004) in his study about university sport models in the United States, Canada, and Australia, emphasized the universities' autonomy power to use the sports as an fundamental identity agenda, and sporting development for the academics and the community, and the career management of services and processes of the academics' sports sections.

\section{CONCLUSIONS}

From this analysis, we present the following conclusions:

The literature review enabled to confirm at first that the professional training of a sporting coach is necessary for the proper direction of training sessions and the athletes at the different competitive levels, however, this does not generate immediate success, it is necessary to review and identify the factors that determine high performance. The influence of the training involved during school age, the number of activities using movement to improve the coordinative development and/or an appropriate transition between the competitive categories, etc.

In a second moment, it is a requirement for the coach to have training and continuous updating of the own knowledge areas of performance; this will be reflected in a technical and pedagogical mastery to individualize planning according to the athlete. In the present investigation, the coaches' postgraduate studies have greater mastery of the theoretical content of sports science.

Influencing indicators of dropout from sporting practice and waste of physicist's skills of the athletes occurs when a coach is not being trained and qualified to do their work properly.

\section{Acknowledgements}

The authors would like to thank Professor Martha Patricia Pérez López for her allowing carry out this research and publication, contributions, ideas, discipline, and dedication helped achieve this result.

\section{Notes}

1. CONADE. Retieved (http://www. conade.gob.mx).

2. CONADE. Retieved (http://www. conade.gob.mx).

\section{References}

Abad, M., F. Giménez, J. Robles, and J. Rodríguez. 2011. "Perfil, experiencia y métodos de enseñanza de los entrenadores de jóvenes futbolistas en la provincia de Huelva" (Profile, Experience and Teaching Methods Coaches Young Players in the Province of Huelva). Revista Retos (Challenges Magazine) 20:21-25.

Aguilar. L. 2003. La educación fisica en el siglo XX (Physical Education in the Twentieth Century). México: Educar.

Ara, N. and P. Saboya. 2006. Métodos, diseños y técnicas de investigación psicológica (Methods, Designs and Techniques of Psychologial Research). National University of Distance Education. Madrid, Spain.

Baker, J., S. Horton, J. Robertson, and M. Wall. 2003. "Nurturing Sport Expertise: Factors Influencing the 
Development of Elite Athlete." Journal of Sports Science and Medicine 2:1-9.

Barros, G., I. Ribeiro, M. Arroyo, M. Perla, A. Rosado, T. Sousa, and F. Pereira. 2010. "Autopercepción de las competencias profesionales de los entrenadores de fútbol en función de la experiencia personal y de la formación académica" (Perception of the Profesional Skills of Football Coaches Based on Personal Experience and Academic Training). Cuadernos de Psicología del Deporte (Journal of Sports Psychology) 10(1):23-26.

Feu, S. 2006. "The Profile of the Handball Coaches. The Training Like a Changes Factor." Official College Degree in Physical Education and Science of Physical Activity and Sport Extremadura. Extremadura, Spain.

Feu, S. and S. Ibáñez. 2001. "La visión del entrenador en la transición a través del deporte" (The Vision of the Trainer in the Transition Through Sport). Revista Internacional de Medicina y Ciencias de la Actividad Física y el Deporte (International Journal of Medecine and Science of Physical Activity and Sport) 1(3):177-187. Retrieved (http://cdeporte. rediris.es/ revista/revista3/artentre.htm).

Feu, S., J. García, I. Parejo, M. Cañadas, and J. Sáez. 2009. "Estrategias para la adquisición del conocimiento profesional del entrenador de baloncesto escolar" (Strategies for the Acquisition of Profesional Knowledge School Basketball Coach). Revista Cuadernos de Psicología del Deporte (Journal of Sport Psychology) 9:325-329.

Feu, S., S. Ibáñez, A. Lorenzo, S. Jiménez, and M. Cañadas. 2012. "El conocimiento profesional adquirido por el entrenador de balonmano: experiencias y formación" (The Professional Knowledge Acquired by Handball Coach: Experience and Training). Revista de Psicología del Deporte (Journal of Sport Psychology) 21(1):107-115.

Feu, S., S. Ibáñez, and M. Gozalo. 2010. "Influencia de la formación formal y no formal en las orientaciones que adoptan los entrenadores deportivos" (Influence of Formal and Non-formal Training in the Guidelines Adopted by Sports Coaches). Revista de Educación (Journal of Education) 353:615-640.

Gonzalez, J., A. Monterrey, and C. De las Cuevas. 1989. "Sport and Psychopathology." Psiquis 10:208-211.

Guillen, D. and O. Ricarte. 2014. "Professional Knowledge of Handball and Football Coaches National Olympiad." Bachelor thesis, University of Colima.

Guinan, D. 2002. "A Survey of U.S. Atlanta and Nagano Olympians: Variables Perceived to Influence Performance." Research Quarterly for Exercise and Sport 73(2):175-186.

Hernández, Fernández, and Baptista. 2009. Metodología de la Investigación (Investigation Methodology). México: McGraw-Hill.
Ibañez, S. and J. Medina. 1999. "Relaciones entre la formación del entrenador deportivo y la formación del professor de educación física" (Relations Between Sports Trainer and Training Physical Education Professor). Apuntes Educación Física y Deporte (Notes Physical Education and Sport) 56:39-45.

_. 2000. "Aportaciones desde la formación del profesor de educación física hacia la formación del entrenador deportivo" (Contributions From the Formation of Physical Education Teacher Training to Sports Coaches). Educación Física y Deportes (Physical Education and Sports) 24. Retrieved (http://www. efdeportes.com/).

—. 2006. "Relación entre la formación del entrenador deportivo y la formación de educación física" (Raletionship Between the Formation of the Sports Coach and Physical). Revista Educación Física y Deportes (Journal Physical Education and Sports) 56(2):39-45.

Irwin, G., S. Hanton, and D. Kerwin. 2004. "Reflective Practice and the Origins of Elite Coaching Knowledge." Reflective Practice 5(3):425-442.

Jiménez Fuentes, F. 2003. "El entrenador en la iniciación deportiva" (Coach the Sports Initiation). Pp. 37-53 in Iniciación deportiva: La Enseñanza y el aprendizaje comprensivo en el deporte (Sports Initiation: Tecaching and Lerning Comprehemsive in Sports), edited by F. Castejón, F. Jiménez, F. Fuentes, and V. López. Spain: Wanceulen.

León, G., F. Dorticós, A. Camacho, and F. Castroy Zamarripa. 2007. "Diagnostic of the Current Situation of Preparation of the Athlete in Municipality of Cajeme." Unpublished text, Techonological Institute of Sonora, Cajeme, Sonora, Mexico.

López, J. and C. González. 2012. "La formación de técnicos deportivos en España. Análisis de una modalidad en desarrollo: El Surf" (Sports Training Technician in Spain. Analysis of a Developing Mode: The Surf). Revista Española de Educación Física y Deportes (Journal of Physical Education and Sports) 397:117-130.

López, R. 2004. Los saberes del entrenador de balonmano. Comunicaciones Técnicas de la Real Federación Española de Balonmano (Knowledge of Handball Coach. Technical Communications of the Royal Spanish Handball Federation). Retrieved (http://www.rfebm.com/PCTECN17. HTM).

Martens, R. 1997. Successful Coaching: The Bestselling Coaching Book. Champaign: Human Kinetics.

Martín, J. and G. Ruiz. 2010. "El entrenador de alto rendimiento deportivo y su contraste con entrenadores de menor nivel: Estudio en la modalidad de karate en España" (The High Performance Sports Coach and Its Contrast With Lower Level Coach, Study in Karate Mode in Spain). 
Motor Science of Physical Activity 24:107-119.

Medina, R., C. Salazar., G. Manzo, C. Peña, and J. Gómez. 2012a. "El imaginario de los estudiantes mexicanos aceptados a carreras en Cultura Física y Deporte" (The Imaginary of Mexican Students Accepted to Carrer in Physical Culture and Sports). Revisa de fisiología del ejercicio FOD (FOD Excersice Physiology Magazine) 7(7):64-74.

Medina, R., C. Salazar, G. Manzo, J. Gómez, and J. Flores. 2012b. "La recreación en el curriculum de los profesionales de educación física y deporte en México" (Recreation in the Curriculum of Professional Physical Education and Sport in Mexico). Revista Latinoamericana de recreación (Latin America Journal of Recreation) 1(2):33-45.

Méndez, O. 2012. "Conocimiento profesional de los entrenadores de Tenis del Estado de Colima" (Professional Knowledge of Coaches Tennins State of Colima). Bacherlor thesis, University of Colima.

Moreno, M. and F. Del Villar. 2004. The Sports Coach: Practical Manual for Development and Training. Vol. 29. Inde.

Nava, A., P. Flores, and A. Gómez. 2013. "Diangósitco de las habilidades profesionales de los entrenadores selectivos del Insttuto Tecnológico de Sonora" (Diagnosis of Occupational Skills of Trainer Selective of Thecnological Institute of Sonora). EFdeportes, Digital Magazine, 18, 188. Retrieved (http://www.efdeportes.com/efd188/las-habilidades-profesi onales-de-los-entrenadores.htm).

Platonov, V. 1999. El entrenamiento deportivo, Teoria y metodología (Sports Training, Theory and Methodology). Spain: Paidotribo.

Runne, K. 1995. "La reformulación de la formación académica del entrenador" (The Reformulation Academic Training Coach). Perfiles Educativos (Education Profiles) 68:1-8.

Santoyo, R. 2012. Historia de la Educación Física en México (History of Physical Education in Mexico). Retrieved (http://dialogoentreprofesores.blogspot.mx/2012/03/historia -de-la-educacion-fisica-en.html).

Sanz, D., Fuentes, M. Moreno, D. Iglesias, and F. Del Villar. 2004. "Influencia de un Programa de Supervisión Reflexiva sobre la Conducta Verbal del Entrenadopr de Tenis en Silla de Ruedas de Alta competición" (Influence of a Program of Reflective Supervision on the Verbal Bahavior Coach of the Wheelchair Tennis High Competition). European Journal of Human Movement 12:107-129.

Sport Science Dictionary. 1992. The Sports Coach. Malaga: Unisport.

Terol, M. 2004. Estudio sobre los modelos de deporte universitario de Estados Unidos, Canadá y Australia. Ministerio de Educación (Study on College Sports Models in the United States, Canada and Australia. Ministry of
Education). Spain: Culture and Sports.

Urzúa, A. 2013. "La formación profesional de los entrenadores de Tenis del Estado de Colima." (The Training of Trainers Court of State of Colima). Bachelor thesis, University of Colima, Colima.

Villalpando, I. 2013. "Chapter 21 Mexico." Pp. 281-299 in Comparative Sport Development: System, Participation and Publi Policy, edited by Hallmann and Petry. London: Springer.

Yague, J., A. Fraile, and Rodriguez. 2004. "Un modelo de formacion permanente del entrenador de futbol" (A Model of Permanent Training of the Football Coach). Apunts 75:50-55.

Zorrilla. 1999. Introducción a la metodología de la investigación (Introduction to Research Methodology). México: Aguilar León.

Zueck, C., A. Chávez, and H. Blanco. 2009. Facultad de Educación Física y Ciencias del Deporte. Historia y Reforma Curricular (Faculty of Physical Education and Sports Science. History and Curriculum Reform). Chihuahua: University Texts UACH.

\section{Bios}

Ciria Margarita Salazar, MA in social sciences, Ph.D. in physical education and arts, University of Extremadura, Spain; full-time researcher and professor in the School of Educational Sciences at the University of Colima, México, member of the Researchers' National System (SNI), Director of the Research Network of sport, physical education, leisure and recreation; research fields: training of teachers and sports coaches, physical culture and city.

Julio Alejandro Gómez Figueroa, Bachelor in physical education sport and recreation, Diploma in sports management, MA in applied science in physical activity, Ph.D. in education; full-time tenured professor " $\mathrm{C}$ " in the School of Physical Education, University of Veracruz, México, desirable profile PRODEP. Leader of Academicians UV-CA-292 "Physical Education and Health"; research fields: physical activity and health.

Martha Patricia Pérez López, BA in English language, BA in physical educaction, University of Colima, México, MA in development of motor functions, University of Puebla, México, professor in the School of Educational Science, University of Colima; research field: coache's training.

Carmen Silvia Vargas Peña, BA and MA in pedagogy, University of Colima, México, full-time researcher and professor assigned to the Degree in High Education Specialized in Mathematics Education at the School of Educational Sciences, University of Colima, México, guest professor in the Master's degree in pedagogy in the same university; 
coordinator of the Technical Council of Evaluating Committee in Pedagogy and Educaction Programs (CEPPE); research fields: institutional evaluation, teachers' staff training in physical activity culture, sports and curriculum.

Pedro Julián Flores Moreno, BA in exercise science from Technological Institute of Sonora, México, MA in Sports Training Methodology at the Valle del Fuerte University, Sinaloa, México, full-time researcher and professor in the School of Educactional Sciences, University of Colima, México; research fields: physical activity and sports.

Rossana Tamara Medina Valencia, MA in recreation and leisure management, Miguel Hidalgo University, Tampico, Mexico, Ph.D. in physical education and art, University of Extremadura, Spain, full-time researcher, professor, and academic coordinator of the Degree in Physical Education and
Sports in the School of Educational Sciences, University of Colima, México; research fields: physical education, training of teacher leisure and recreation.

José E. Del Rio Valdivia, graduate in medicine, University of Guadalajara, MSc in science, Biomedical Research Center, University of Colima, México, Ph.D. in exercise physiology, Biomedical Research Center, University of Colima, México; Principal at School of Educational Sciences, University of Colima, México; research fields: health, physiology excersice, sports medicine and nutrition.

José Aldo Hernández-Murúa, Ph.D. in physical activity and sports, professor, School of Physical Education, University Autonomous of Sinaloa, México; research fields: coaching of trainers, functionality and muscular power training, health and quality of life. 